This is a self-archived - parallel published version of this article in the publication archive of the University of Vaasa. It might differ from the original.

\title{
The role of stakeholder banks in European banking sector.
}

Author(s): Kalmi, Panu

Title: $\quad$ The role of stakeholder banks in European banking sector.

Year: $\quad 2017$

Version: Accepted manuscript

Copyright (C) 2017 the author | Palgrave Macmillan, Cham. Published by Springer International Publishing

Please cite the original version:

Kalmi, P., (2017). The role of stakeholder banks in European banking sector. In: Miklaszewska, E. (ed.) Institutional Diversity in Banking : Small Country, Small Bank Perspectives (p. 33-50). Palgrave Macmillan, Cham. https://doi.org/10.1007/978-3-31942073-8_2 


\title{
The Role of Stakeholder Banks in European Banking Sector
}

Panu Kalmi, University of Vaasa

\begin{abstract}
Socially oriented financial institutions have an equally long history than profit-oriented financial institutions in Europe. Stakeholder banks occupy a unique and important position in the European banking sector and they have been credited to stabilize the financial market. Changes in financial markets have also caused significant changes in the operations of stakeholderoriented institutions, leading to significant convergence of the profit-maximizing sector and the stakeholder banks. At the same time, stakeholder banks have remained true to many of their original characteristics. The tensions between regulatory and competitive pressures on the one hand, and the need for a more diverse financial sector on the other hand will continue to characterize the European banking market for years to come.
\end{abstract}

\section{The origins of stakeholder banks}

Profit-maximizing ownership structures in banking have been accompanied throughout the history of banking by not-for-profit structures. This can be traced to the social importance of the credit and saving services, to the vulnerability of a large segment of consumers in this area, and to imperfect competition that characterizes the sector. The modern forms of these financial institutions are cooperative and savings banks. They have a multifaceted history which is briefly reviewed below.

Modern banking can be perceived to have its origins in renaissance Italy (Parks, 2013). Already aside the banks of Medici and other wealthy families, there emerged (often sponsored 
by these same families) a network of "mounts of piety" (monte di pieta in Italian). These organizations were well known also in Spain and France. These were basically charities that were operated by the Catholic Church (Menning, 1993). The operated much like pawnshops: loans were given against tangible securities, which were possessed by the institution for a prespecified maturity. The borrower could repossess the security by paying the principal and a modest amount of interest. In addition to the interest margin, the operational costs were covered by donations of wealthy individuals. Even though the Catholic Church at the time denounced usury (in general, charging the interest), it was approved in the case of mounts of piety, which were typically operated by Franciscan friars. The lack of profit motive and the social service provided through loans to financially excluded persons made this service acceptable to the clergy.

Mounts of piety were precursors for savings banks, which appeared independently in Scotland, Germany and France early in the $19^{\text {th }}$ century and quickly spread through many countries (Wysocki, 1996). While the Scottish savings bank concept was based on private philanthropy, and also some of the first continental European savings banks were based on the private initiative, the German model where savings banks were established by the public sector (municipalities) became very successful and is influential up to this day. However, private savings banks (sometimes with elements of hybrid forms between private and public sector organizations) have been prevalent for instance in Spain or the Nordic countries. Savings banks became relatively common throughout Europe in the $19^{\text {th }}$ century. In many European countries (for instance, the UK) also government-owned public savings banks became important.

Savings banks are akin to non-profit companies with no party sharing both the rights to revenues and rights to control (Hansmann, 1996). Non-profit structure protects vulnerable 
stakeholders from being exploited by strong interest groups. An example of this would be excessive risk-taking in the name of shareholder interests. Non-profit structures remove this interest conflict. These issues may have been especially topical in the context of early $19^{\text {th }}$ century, when deposit insurance was lacking, consumer protection weak and the average understanding of depositors on economic issues (financial literacy in modern parlance) deficient.

While savings banks are in charity-based and rather paternalistic in structure, around the middle of $19^{\text {th }}$ century cooperative financial institutions were developed as an alternative to them. The standard history of financial cooperatives places the development of cooperative institutions in Germany (e.g. Faust, 1965). A member of the Prussian parliament, Hermann Schulze-Delitzch established a financial cooperative in his hometown in 1850, which is often regarded as the first financial cooperative. The first rural cooperatives were started by F.W. Raiffeisen during the mid-1860s.

Despite this standard history, there are instances of financial cooperatives pre-dating the German credit cooperatives. One important example of this are building societies that were developed especially in the UK, the first one being possibly Ketley's Building Society in Birmingham, established in 1775 . The idea in building societies was that a group of people could come together and collectively pledge security for their housing project, making it much easier to obtain loans from financial institutions (Ashworth, 1980). The societies used member savings and real estate for their collateral. They were mutually governed by their members. The first building societies were of temporary kind, dissolving once initial group of members had finished their housing project. However, during mid- $19^{\text {th }}$ century the societies evolved into permanent types, where members could retain their deposits for an indefinite period. This marked their transition into permanent type of financial institutions. 
Other types of financial cooperatives have also existed in history. For instance, Francois Haeck and his associates established in Brussels a mutual financial institute called Union du credit de Bruxelles (Lumley, 1857), and apparently similar organizations existed at least in Belgium and Switzerland (Wolff, 1896). However, little is known about them today.

However, it is justified to focus on German cooperative banks, because they are forerunners with a great majority of financial cooperatives today, including also North American credit unions that usually trace their history back to Raiffeisen cooperatives. In the following, we focus on the key differences between Schulze's and Raiffeisen's financial cooperatives, and also contrast them with savings banks.

\section{Historical cooperative banks}

A key defining feature of cooperative banks - or any cooperative - is their adherence to one member- one vote standard. This structure was also present in Schulze's cooperatives that mostly gathered its members from urban middle classes. Membership in these cooperatives required investment in equity, the members could expect to receive dividends (in addition to improved credit access and lower rates). Members enjoyed limited liability, so they were protected against unexpected losses. The loans were usually of relatively short maturity.

Raiffeisen adopted many key features from Schulze's cooperatives, but modified them in very significant way. The main goal of Raiffeisen's cooperatives was to relieve and poor small farmers from the pressures of usurers. In $19^{\text {th }}$ farming, income is generated primarily after harvest and much of the income is generated in short period, whereas investments (in seeds etc.) is required in the start of the growing season and quite far removed in time from main income flows. Because of this temporal mismatch and also because of occasional poor harvests, small 
farmers were easy prey for usurers. Farmers could not get loans from outside financial institutions because of the lack of collateral.

Raiffeisen's cooperative banks made several innovations that made long-term borrowing by poor farmers possible. First of all, they pooled the modest savings of the farmers, and made it possible to borrow collectively against this pool of savings. Furthermore, all members of Raiffeisen's cooperatives had an unlimited liability of the debts of the cooperative, further generating trust that outside lenders could recoup their loans. The loans could also be redeemed in two weeks' notice, although in principle they were of much longer maturity. Members were not required to make equity investments. Instead, equity was accumulated through retained earnings. In the absence of individually-owned equity, there were also no dividend payments to members (Prinz, 2002).

Unlimited liability could potentially put vulnerable farmers into quite vulnerable position. These issues were solved by heavy screening of members and monitoring of member behavior, and detailed regulation of member rights and duties (Guinnane, 2001). Initial Raiffeisen cooperatives were also rather small and typically consisted of members of one village only. In this way, it could be ensured that there were tight personal relationships between members, generating social pressure to repay the loans. Typically the directors of Raiffeisen cooperatives were large farmers, priests of school teachers. This further generated public trust towards these organizations.

The differences between Schulze's and Raiffeisen's cooperatives are quite marked (Faust, 1965). The absence of profit motive, the primacy of service over profit, and cultivation of collective responsibility over individual self-interest were hallmarks of Raiffeisen's cooperatives, 
whereas Schulze's cooperatives relied much more on individual self-interest of members. These differences produced also a "clash of methods" between the leaders of the respective groups, which lead into a division of cooperatives into two competing groups. Schulze's ideas generated a group of “popular banks”, whereas Raiffeisen's credit cooperatives served as examples for rural credit cooperatives. Over time, these differences and tensions were resolved and for instance in Germany eventually the banks developed a joint apex organization. However, in many countries (e.g. Austria, France, Italy) the dualism in the movement of financial cooperatives remains until to this day.

The German cooperative movement spread very quickly all over Europe, first to the neighboring countries (Wolff, 1896). The first credit cooperatives (popular banks) were established in France, Italy and Austria already in the 1860s. The Raiffeisen cooperatives started to spread later for natural reasons, but even they were quite commonly adopted in 1880 s. The innovations spread gradually outside Germany, so they reached the Nordic countries generally around early $20^{\text {th }}$ century. Of the Nordic countries, they became important only in Finland, and even there they became so mostly after the WWII (Kalmi, 2012).

The network structures of cooperative banks were created already in the early forms of financial cooperatives and they were especially important for the small scale Raiffeisen cooperatives. There were different tasks for the networks. One were purely operational: organizations of payments within the group and across other financial institutions, being the counterparty in respect to central bank and other financial institutions, liquidity management and risk management within the group etc. The other task were related to increasing the visibility of the group, auditing services, lobbying towards the government, maintaining the homogeneity 
within the group, organizing training, and so on (Guinnane, 2003). Similar network services, though perhaps at a smaller scale, characterized also groups of popular banks.

\section{Cooperative and savings banks today}

Though the initial circumstances under which cooperative and savings banks were created have disappeared, this has not led to the disappearance of these institutional forms. In fact, cooperative banks may now be stronger in Europe (at least in terms of market shares) than in any previous point of time, whereas savings banks have been much more under threat.

Cooperative banks are either individually or collectively market leaders in several European countries (Fonteyne, 2007; Karafolas, 2016). Collectively their impact is largest in France, where the three cooperative groups have a market share in retail banking over $50 \%$. Cooperative have market shares over one third in Austria, Italy, Finland and the Netherlands. They still have a significant presence in their country of origin, Germany. In many countries, the market shares of cooperatives have been increasing, especially after the financial crisis. However, there are also cases where cooperative banks have almost disappeared, such as Belgium and Sweden. In East Europe cooperative financial organizations were wiped out during socialism and they have had problems in re-emerging, except in Poland where they are relatively strong (Miklaszewska and Kil, 2014).

The record of savings banks is much more mixed. Still in early 1980s, they tended to be market leaders in the Nordic countries, Spain and Germany, with significant presence in Austria, Belgium and Italy (Ayadi et al., 2009). However, the deregulation had led to conversions into joint-stock company forms in countries such as Belgium, Denmark and Italy during the 1980s1990s. In some of the Nordic countries (especially Finland, but to some extent also Norway and 
Sweden) the financial crisis of late 1980s / early 1990s led to the decline of the savings banks sector. More recently, the problems of the Spanish savings banks sector in the crisis of the 2010s has attracted a lot of attention. Out of over 40 savings banks still in 2009, only 2 continue as savings banks, the rest having merged and converted into joint stock banks.

While the sector of private savings banks has been generally in demise already during some decades, the public savings bank sector has proven to be much more resistant. In Germany, there has been problems associated with the central organizations of the savings banks sector (Landesbanken), whereas the local savings banks have managed to go through the crisis more or less unharmed. Also in Austria, which is another instance of a strong public savings bank movement, the savings banks have not been much affected by the crisis.

The strong performance of cooperative banks and public savings banks in terms of market share indicate that these banks do perform a valuable contribution to today's banking services and they have successfully adapted their business models. However, as these banks have a "double bottom line" and generate social value-added in addition to the economic one, traditional performance indicators such as survival and profitability may not be sufficient for a comprehensive evaluation of their performance.

Raiffeisen cooperatives especially may be viewed as forerunners of ethically sound and sustainable banking, which has become more appealing after the financial crisis. At the same time, many experts have asked whether "cooperative banks have lost their soul?" (Ory et al., 2012). In other words, cooperative banks are argued to have become more like commercial banks and therefore unable to perform its role in adding diversity to the banking market structure. This is an important question and it suggests several lines in inquiry. To the extent that such 
convergence has occurred, it is important to ask whether it has occurred in all dimensions or just some, and whether cooperatives (or stakeholder banks in general) still perform a valuable (and distinct) service in other margins. Another important question to ask is what are the reasons behind these changes: are they result of internal process of stakeholder banks, or regulation, or both?

\section{The role of networks in cooperative and savings banks}

Two mistakes are common in the analysis of modern European stakeholder banks, at least if we are discussing tightly integrated cooperative banks or German and Austrian public savings banks groups. One can either focus on grass-root entities and make conclusions on the basis of their predicted behavior; or alternatively, focus on central units only and argue that they represent the entire group. Both of these approaches lead into mistaken conclusions, although they err in different ways. The first approach tends to view cooperative banks as small, focusing on retail markets and traditional intermediation only, and suffering from significant corporate governance problems. The other view tends to view cooperative groups as single centralized entities, carrying out policies laid out at the top of the hierarchy and sees virtually no role for local banks other than deposit collection. Often these two views are somehow combined by noting that stakeholder banks initially were of the first type, and later the structure emphasizing the centrality of the apex organizations has taken over.

While all of these views have some important elements of truth, all of them contain problems as well. First, as noted earlier, networks have been an important part of the concept of cooperatives and savings banks since the very beginning, so they are not new. Another important issue is that the networks are to a real and significant extent controlled by local cooperative 
banks due to governance structures that actually put the local banks at the top of the pyramid. This control is usually shared by the managers and owner representatives of local banks, but in any case it ensures that also other interests than those of top managers are taken into account when making decisions. This is not to say that all local banks are equal; usually the decisionmaking power is more concentrated among larger banks.

How do networks make stakeholder banking groups different? In the absence of networks, stakeholder banks would be larger and more focused on traditional intermediation; in fact, these differences can be observed when comparing tightly integrated cooperative banks with loosely integrated cooperative banks (Ferri et al., 2015). In other words, integration allows cooperative banks to maintain smaller feasible scale, which may be good in terms of maintaining member participation (Jones and Kalmi, 2012). It also allows them to pursue other income sources than interest income, which is beneficial in terms of diversification (Ayadi et al., 2010). Networks are also very useful in solving the corporate governance problem at the level of primary cooperatives: while the members of primary level cooperatives cannot realistically monitor the management very closely (neither do they need to, due to deposit insurance), the situation is rather different for cooperative groups, which often provide also auditing services to primary cooperatives. Bad performance due to managerial failures is much more easily observed and disciplined by the network rather than the local members (Desrochers and Fischer, 2005).

However, it is true that there is also a downside of having strong networks. In some cases, the networks are organized as listed companies (as for instance in Credit Agricole). This brings the interest of outside shareholders to the governance process of cooperatives and has potentially disruptive effects. At least the cooperative now must weigh the profit motive much more closely in the decision-making (Ory and Lemzeri, 2012). The network structure may also induce risk- 
taking in other ways. One of the most controversial issues is the internationalization of cooperative banks to foreign markets, especially to East Europe. Among others, the Austrian Raiffeisen Group and the Austrian Savings Banks Group through its central organization Erste Bank, and the French Credit Agricole have been very active in spreading out to foreign markets. Sometimes the internationalization has been a source of fatal problems; for instance, a large part of the losses of the Austrian Volksbank Group that has brought the group on the verge of bankruptcy has been due to the operations of the (now defunct) Volksbank International, the arm of the group in the internationalization process.

More generally, the networks may play a central role in institutional isomorphism process, where cooperatives become over time more similar to their competitors. This is especially harmful, if we believe that cooperatives should promote institutional diversity in the banking market.

Parallel to change in network structure, there are also important changes going on in local level cooperatives. Even though the Raiffeisen ideal of very small cooperatives where members possess detailed information about each other has been abandoned a long time ago, the consolidation of local level of cooperatives is still ongoing. This has been taken to its logical extreme in the Dutch Rabobank Group, which has since January 2016 operated as a single cooperative without the local level cooperatives (Groeneveld, 2016). Elsewhere the changes have been less drastic, but mergers of local cooperatives and a reduction in their number has occurred elsewhere. In many cases, this can be justified in terms of higher operational efficiency. However, it has a cost in terms of weakened participation and social bonds among the members (Jones and Kalmi, 2012). The process is also partly influenced by the regulatory developments: increased compliance costs necessitate lead to a larger optimal size of local level cooperatives, 
thus prompting mergers that may not be optimal in situations of more neutral regulation (Ferri and Kalmi, 2014).

Given that the role of networks in stakeholder banks seems to have evolved over time and their importance appears to have increased and there seems to be some kind of convergence towards the behavior of investor-owned banks, is this more due to external or internal circumstances? A plausible answer is that both elements are at play. Internally, a more powerful group with investments abroad is appealing to the top management of the banking group. A board that has a strong orientation towards traditional intermediation, focus on local markets and a moderate degree of risk taking, even at the expense of weaker growth, may be a countervailing power, and sometimes they have been successful in curtailing managerial ambitions leading to different strategies (or being successful for choosing cooperatively minded managers). But other times ambitions management has prevailed.

Even though the narrative focusing on internal reasons seems convincing to those suspecting that the main problems with cooperatives can be located in their corporate governance, it is far from the full story. An important reason for the change in the role of networks is related to external circumstances and regulation. One of the important elements in the change towards tighter integration is regulation and the stress towards joint liability of member banks. The forerunners in this have been the Dutch Rabobank group and the Finnish OP Group. In Finland, the decision to adopt the tightly integrated model were related to the experiences of the banking crisis of the early 1990s (Kalmi, 2012). The management of the central organization felt that it could not discipline member banks that took excessive risk and some banks could free ride on joint organizational capital of the group. The group could not allow banks in the group fall without being rescued, because the contagion effects would have endangered the survival of the 
entire group. The new structure was intended to give tools for the management to address this kind of problems. At that time, a minority of cooperative banks actively opposed to the integration process and they formed a group of their own in 1997, called the POP Group. The irony of history is that after almost 20 years of successful operations, the POP Group was forced in 2015 also to adopt a joint-liability structure, due to changed liquidity regulations in Basel III. The joint liability structure have been proposed also to cooperative banks elsewhere, for instance to the Italian banks within the BCC Group.

\section{Operational differences between stakeholder banks and shareholder banks}

One way to look at the differences between stakeholder banks and shareholder banks is to see whether there are systematic differences in the balance sheets. One key prediction why these two types of banks might be different are the attitudes towards risk taking. In shareholder banks, the typical high leverage of banks gives managers high incentives towards risk-taking. In stakeholder banks, the advantages of risk taking are much more muted. First, the profit distribution in both cooperative and savings banks is typically much more limited than in shareholder banks. The increase in earnings would primarily increase the capitalization of stakeholder banks. The lack of a group that would clearly benefit from excessive risk taking is a powerful deterrence of it. From this, there flows several related hypotheses. Because stakeholder banks are not profit-maximizing and have lower incentives towards risk-taking than shareholder banks, they can be expected to be less profitable. On the other hands, because of lower risktaking, they should have lower volatility of profits. Because of the relationship lending strategies they employ and because of lower risk taking, they can be expected to have lower loan losses as well. 
The aftermath of the financial crisis of 2007-2008 offered a useful point of view on these issues. Financial crisis has often been regarded to be a result of excessive risk taking and greed. To the extent that stakeholder banks manage to provide countervailing power against these outcomes, it would increase the argument in their favor. Fortunately, there is a series of crosscountry studies that have been done using the Bankscope database that shed light on these issues.

Hesse and Cihak (2007) were among the first authors who pointed out that stakeholder banks could be more stable than other banks. They made this argument on the basis of "distance to default" z-scores, that are based on the ratio between the sum of profitability and capitalization divided by the standard deviation of profitability. They find that even though stakeholder banks had lower profitability and capitalization than shareholder banks, the markedly lower volatility of profits raised the z-scores of stakeholder banks above that of shareholder banks.

The notion of lower profitability of stakeholder banks compared to shareholder banks has been made for instance by Iannotta et al. (2007). However, Ferri et al. (2015) find that this holds true only for the pre-crisis period. During the crisis year, there was a marked convergence between the profitability of shareholder and stakeholder banks, so on average differences could no longer be detected.

Other studies present evidence on the lower volatility of stakeholder banks when contrasted to shareholder banks. Ferri et al. (2014a) show that especially tightly integrated cooperative banks experience less downgrades by rating agencies than shareholder banks. Ferri et al. (2014b) show that lending of stakeholder banks is less responsive to changes in monetary policy, which they interpret being an outcome of the relationship lending practices of stakeholder banks. Meriläinen (2016) finds that stakeholder banks reduce their lending after the crisis less than 
shareholder banks. Meriläinen (2015) also finds that the loan loss provisions of stakeholder banks are less cyclical than those of shareholder banks.

There are certain differences across ownership structures. Generally speaking, based on the studies that make fine-grained distinction between the ownership structures (especially Ferri et al. 2014a and 2015) tightly integrated cooperative banks and public savings banks are the groups that seem to fare best in the crisis, whereas private savings banks do not differ very much from shareholder banks. This is evidence on the benefits of tighter integration.

One further issue among the performance of cooperative and savings banks are whether these banks are able to produce positive externalities to enterprises and regions. Examples include improved credit access of SMEs due to relationship banking, financial inclusion and more equal regional development. These arguments have often been made, but it is difficult to get much hard evidence on this. One exception is the study of Hasan et al. (2014), who show based on a sample of Polish cooperative banks that they are more likely to lend to local enterprises than either foreign- or locally-owned shareholder banks. It is also well-known that stakeholder banks and especially cooperative banks have much more branches per assets than shareholder banks and use more labor-intensive lending techniques. In many cases, if stakeholder banks would change their business strategy which is based on the principle of regional presence, many sparsely populated regions would be under threat of becoming underserved.

\section{Differences in the performance of savings and cooperative banks}

One of the most striking issues in the development of cooperative and savings banks in the past few decades, though seldom commented, has been the diverging track record of cooperative versus saving banks. Cooperative banks have for the main part been able to increase their market 
shares, whereas saving banks have been losing ground rapidly. To be sure, this is a development fueled not only be competitive market pressures: savings banks have also in some cases been forced to convert to other structures, whereas cooperative banks have usually not been exposed to a similar pressure. An exception in this case is the Italian popular banks (Banche Popolari). The Italian regulators have started a process with the aim to convert these banks into shareholding structures. However, such cases have been rare so far.

Despite this, there have also been cases of business failures of savings banks, the Spanish case being the most spectacular one. In theory, there should not be that much difference between cooperative and savings banks in terms of corporate governance: while the latter have no proper owners, in the case of cooperative banks the owners are so small that they cannot be reasonably expected to be able to influence bank behavior. However, cooperative members do actually contribute a membership fee (and occasionally additional equity) and this may well change their relationship with the cooperative. Jones and Kalmi (2015) find that cooperatives that have more successfully recruited members from their pool of customers do have better performance than cooperatives have lower membership ratios. The possibility to contribute equity capital makes also cooperative banks more resilient in crisis situations compared to savings banks. This suggest that the economic role of membership in cooperative banks may be more significant than often assumed.

\section{Conclusions: External and Internal Diversity}

This article has shown how not-for-profit structures have evolved in the history of banking. Their coexistence through centuries strongly suggests that there are many benefits for the financial industry to compose of organizations with differing objectives, ownership structures 
and business models. This "financial biodiversity" argument is by now familiar (Haldane, 2010; Michie, 2011; Goodhart and Wagner, 2012). Many studies cited in this paper also support the argument that the operations of stakeholder and shareholder banks do differ from each other.

However, it is less often noted that diversity in the context of stakeholder banks can be divided into two different components, which I will call here "external" and "internal" diversity. External diversity refers to the differences between shareholder and stakeholder banks: this is what usually covered by discussion of diversity. The "internal diversity" refers to the heterogeneity within stakeholder banks. As I have noted in this article, the predecessors of stakeholder banks came in multitude of forms, some of which have probably been already forgotten. Today's stakeholder banks took shape from these diverse origins.

It is important to recognize the role of variation and experimentation in this process; different forms were tried, and the most functional and adaptive survived. It is natural that stakeholder banks have changed substantially in this process; the banks adapt to the surrounding market structure.

However, it is important to realize that regulations play also a key role in the formation of this diversity. Regulators usually claim to neutral with respect to ownership, but this claim does not hold water. Regulation in many ways forces the banks to be similar to each other. Within stakeholder banks, it also forces the banks to adopt similar structures: the joint liability structure of cooperative groups is an example of that. Even though joint liability makes individual banks more resilient, it may in adverse circumstances make it more likely that the banking group will fail as a whole in cases where otherwise parts of the group could have rescued. The joint liability 
structure poses also challenges to participation in local bank governance. Ultimately it may lead into loss of regional structure, as we have seen in the case of Rabobank.

Although tighter integration has many benefits, as has been explained, it may also come with significant costs. An example is ambitious and often highly problematic ventures into foreign markets by cooperative banks. Another is involvement in toxic securities, a problem that affected many cooperative groups and especially Landesbanken in 2008. Finally, stakeholder banks have not remained immune to high-profile fraud cases in the banking industry. For instance, Rabobank had to pay over 1 billion USD as fines because of their involvement in the LIBOR rigging.

One of the least tangible and therefore hardest to maintain aspect of diversity is the value orientation of stakeholder banks. Explicit value differences have been a hallmark of not-forprofit financial organizations from Monte di Pieta to Raiffeisen rural cooperatives. The need for value-based banking has also been widely recognized in the aftermath of the financial crisis. Because of intangibility of the values, it is also one of the aspects that may easily be lost in the daily business pressures. I have noted elsewhere that social banks, of which many are cooperatives, are today perhaps the most promising source of revitalization of the value-based banking (Kalmi, 2014; Cornée et al., 2016). They are also in many cases relatively new banks. Entry of new banks, which is also made extremely difficult for stakeholder banks due to regulation, is essential for maintaining the vitality of sector.

Stakeholder banks have been part of the financial landscape for several centuries. They play a distinct role in promoting diversity in the banking sector. At the same time, they are now under extraordinary pressure from the regulators to homogenize their operations. Even though this is 
highly problematic from the point of view of their long-term viability, it can be expected that there will be new opportunities stakeholder financial organizations will be able to seize and new organizational forms to be developed. Promising fields would be, for example, the intersection between financial technology and financial inclusion.

\section{References}

Ashworth, H. (1980). The Building Society Story. London: Franey \& Co.

Ayadi, R., Schmidt, R. H., Carbo-Valverde, S., Arbak, E., \& Rodriguez-Fernandez, F. (2009). Investigating diversity in the banking sector in Europe: The performance and role of savings banks. Brussels: CEPS.

Ayadi, R., Llewellyn, D. T., Schmidt, R. H., Arbak, E., \& De Groen, W.P. (2010). Investigating diversity in the banking sector in Europe: key developments, performance and role of cooperative banks. Brussels: CEPS.

Cornée, S., Kalmi, P., \& Szafarz, A. (2016). Selectivity and Transparency in Social Banking: Evidence from Europe. Journal of Economic Issues, forthcoming.

Desrochers, M., \& Fischer, K. P. (2005). The power of networks: integration and financial cooperative performance. Annals of Public and Cooperative Economics, 76(3), 307-354.

Faust, H. (1965). Geschichte der Genossenschaftsbewegung: Ursprung und Weg der Genossenschaften im deutschen Sprachraum. Frankfurt: F. Knapp. 
Ferri, G. \& Kalmi, P. (2014). Only Up: Regulatory Burden and Its Effects on Credit Unions. Madison, WI: Filene Institute.

Ferri, G., Kalmi, P., \& Kerola, E. (2014a). Organizational structure and exposure to crisis among European banks: evidence from rating changes. Journal of Entrepreneurial and Organizational Diversity, 3(1), 35-55.

Ferri, G., Kalmi, P., \& Kerola, E. (2014b). Does bank ownership affect lending behavior? Evidence from the Euro area. Journal of Banking \& Finance, 48, 194-209.

Ferri, G., Kalmi, P., \& Kerola, E. (2015). Organizational Structure and Performance in European Banks: A Reassessment. Advances in the Economic Analysis of Participatory \& Labor-Managed Firms, 109-141.

Fonteyne, W. (2007). Cooperative Banks in Europe: Policy Issues, IMF Working Paper 159 / 07.

Goodhart, C. A., \& Wagner, W. (2012). Regulators should encourage more diversity in the financial system. VoxEU. org, 12 .

Groeneveld, H. (2016). The Road Towards One Cooperative Rabobank, Utrecht: Rabobank.

Guinnane T.W. (2001). Cooperatives as information machines: German rural credit cooperatives, 1883 1914, Journal of Economic History 61(2),366-89. 
Guinnane, T. W. (2003). A “friend and advisor": external auditing and confidence in Germany's credit cooperatives, 1889-1914. Business History Review, 77(2), 235-264.

Haldane, A.G. (2010), “The \$100 Billion Question”, Bank of England.

Hansmann, H. (1996). The Ownership of Enterprise. Cambridge, MA: Harvard University Press.

Hasan, I., Jackowicz, K., Kowalewski, O., \& Kozłowski, Ł. (2014). Bank ownership structure, SME lending and local credit markets. Bank of Finland Research Discussion Paper, 22/2014.

Hesse, H., \& Čihák, M. (2007). Cooperative banks and financial stability. IMF Working Paper $02 / 07$

Iannotta, G., Nocera, G., \& Sironi, A. (2007). Ownership structure, risk and performance in the European banking industry. Journal of Banking \& Finance, 31(7), 2127-2149.

Jones, D. C., \& Kalmi, P. (2012). Economies of Scale versus Participation: A Co-operative Dilemma?. Journal of Entrepreneurial and Organizational Diversity, 1(1), 37-64.

Jones, D., \& Kalmi, P. (2015). Membership and Performance in Finnish Financial Cooperatives: A New View of Cooperatives?. Review of Social Economy, 73(3), 283-309.

Kalmi, P. (2012) 'Finnish Cooperative Banks and the Crisis of Early 1990s' in W.W. Boonstra and J. Mooij (eds.), Raiffeisen's Footprint: The Cooperative Way of Banking, Vrije University Press (Amsterdam), 181-196. 
Kalmi, P. (2014). Ethics, Banking and Ownership, Safe Bank / Bespieczny Bank, 55(2): 27-37.

Karafolas, S. (2016, ed.). Credit Cooperative Institutions in European Countries. Berlin: Springer.

Lumley, W.G. (1857). An Account of the Banking Establishment in Belgium, Termed L'union du Credit De Bruxelles, Journal of the Statistical Society of London, 20(1), 61-65.

Menning, C. B. (1993). Charity and state in late Renaissance Italy: the Monte di Pieta of Florence. Ithaca, NY: Cornell University Press.

Meriläinen, J.M. (2015). The Role of Bank Ownership Type in Cyclicality of West European Banks' Loan Loss Provisions, manuscript, University of Vaasa.

Meriläinen, J. M. (2016). Lending growth during the financial crisis and the sovereign debt crisis: the role of bank ownership type. Journal of International Financial Markets, Institutions and Money (forthcoming).

Michie, J. (2011): Promoting Corporate Diversity in the Financial Services Sector, Policy Studies, 32(4): 309-323.

Miklaszewska, E., \& Krzysztof, K. (2014). The Role of Diversity of Banking Models: Position and Prospects of Polish Cooperative Banks. Bezpieczny Bank, 55(2), 50-64. 
Ory, J. N., De Serres, A., \& Jaeger, M. (2012). Have Co-operative Banks Lost their Soul?.The Me-too Effect of Regulation, in Heiskanen, J., Henry, H., Hytinkoski, P., Köppä, T., New Opportunities for Cooperatives: New Opportunities for People. Helsinki: University of Helsinki, 200-222.

Ory, J. N., \& Lemzeri, Y. (2012). Efficiency and Hybridization in Cooperative Banking: The Frecnh Case. Annals of Public and Cooperative Economics, 83(2), 215-250.

Parks, T. (2013). Medici Money: Banking, Metaphysics and Art in Fifteenth-Century Florence. London: Profile Books.

Prinz, M. (2002). German Rural Co-operatives, Friedrich Wilhelm Raiffeisen and the Organization of Trust, Manuscript, University of Bielefeld.

Wolff, H. W. (1896). People's Banks: a record of social and economic success. London: P.S.King \& Son.

Wysocki, J. (1996). Introduction, in: J. Mura (ed.): History of European Savings Banks, vol. 1, Stuttgart: Deutches Sparkassenverlag, 9-26.

\section{Author biography}

Panu Kalmi is Professor of Economics at the University of Vaasa. Previously he was many years affiliated with Helsinki School of Economics (currently Aalto University). He has been a visiting fellow at Cornell University and University of Victoria (BC). He is a past president of the 
Finnish Economic Association. His main research interests include cooperatives, financial institutions, financial literacy and personnel economics. 